\title{
On Music, Torture and Detention: Reflections on Issues of Research and Discipline
}

Musique, torture et détention : réflexions sur des enjeux de recherche et de discipline

\section{Anna Papaeti}

\section{OpenEdition}

\section{Journals}

Electronic version

URL: http://journals.openedition.org/transposition/5289

DOI: 10.4000/transposition.5289

ISSN: 2110-6134

Publisher

CRAL - Centre de recherche sur les arts et le langage

\section{Electronic reference}

Anna Papaeti, «On Music, Torture and Detention: Reflections on Issues of Research and Discipline », Transposition [Online], Hors-série 2 | 2020, Online since 15 March 2020, connection on 16 April 2020 URL : http://journals.openedition.org/transposition/5289; DOI : https://doi.org/10.4000/transposition. 5289

This text was automatically generated on 16 April 2020.

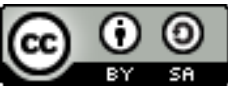

La revue Transposition est mise à disposition selon les termes de la Licence Creative Commons Attribution - Partage dans les Mêmes Conditions 4.0 International. 


\section{On Music, Torture and Detention: Reflections on Issues of Research and Discipline}

Musique, torture et détention : réflexions sur des enjeux de recherche et de discipline

\section{Anna Papaeti}

\section{AUTHOR'S NOTE}

I am grateful to the guest editor of this issue Luis Velasco-Pufleau and to Martin Daughtry for their valuable commentary, as well as to Athena Athanasiou for many thought-provoking discussions over the last two years. This essay is based on research conducted in the context of a Marie Skłodowska Curie Individual Fellowship (acronym MUSDEWAR 706016) held at the Department of Social Anthropology at Panteion University of Political and Social Sciences, Athens (2017-2019).

$1 \quad$ Musicology and ethnomusicology have been historically and ideologically founded on the notion of music as an inherently positive, benign and ennobling artform. As such, these fields took long to engage with music's long-standing association with violence, war and power, dating back to the Middle Ages if not earlier; ${ }^{1}$ the study of Nazi concentration and extermination camps is a notable exception, although it was also examined relatively belatedly. ${ }^{2}$ Left unexplored by historians, social anthropologists, human rights scholars, and legal experts working in the field of violence, detention and justice, this gap began to be critically addressed in music research only in the last decades. In this essay, I explore (ethno)musicology's latent reaction to music's relationship with violence and technologies of terror as a disciplinary trauma, critically discussing a wide range of effects stemming from this silencing. Also investigated are the cultural biases that have turned music into an elusive means of torture, the practice of music torture, its impact and the legal context that has made it possible. 
Addressing the intersections of music and terror, I underline the need for more nuanced soundscapes of detention that explore the entanglement of negative and positive uses of music imposed from above and reclaimed from below.

\section{Music, Violence and Torture: A Disciplinary Blind Spot}

2 Although movements in the USA and the UK such as new musicology and critical musicology stretched the boundaries of the discipline during the last decades of the twentieth century, enriching it with new areas of study and theoretical approaches, research on music's association with violence remained at the fringes of both musicology and the more progressive discipline of ethnomusicology. Commenting on this latent response, Timothy Rice has noted how ethnomusicology, up until the late twentieth century, focused on the positive role of music for the individual, communities and local societies, contrary to anthropological research which, quite early on, examined issues of violence, methods and mechanisms of repression by authoritarian regimes. ${ }^{3}$ Musicology followed suit with some delay.

3 Catalyst to this turn were testimonies of detainees from the US naval base at Guantanamo, Cuba and the Abu Ghraib prison in Iraq, bringing to the fore the institutionalized use of music and sound in torture in the so-called War on Terror. Opening Pandora's box, these accounts initiated changes institutionally, as well as in music research in the USA and Europe. Gradually challenging rigid understandings of the discipline of musicology itself, these changes called for a re-examination of its boundaries, methodologies and ideologies. ${ }^{4}$ Signs of this turn initially took the form of resolutions passed by music societies in the USA, condemning the use of music torture by the USA: resolutions were issued in 2007 by the Society of Ethnomusicology (SEM) ${ }^{5}$ and the Society for American Music (SAM), ${ }^{6}$ and in 2008 by the American Musicological Society (AMS). ${ }^{7}$ On the other side of the Atlantic, there was notable silence from respective music associations in the UK, even though this was a country also involved in the "War on Terror", implicated in extraordinary renditions, torture and inhuman treatment of detainees. Prompted on separate occasions by researcher Katia Chornik in 2017 to consider the possibility of making public statements about political incidents, both the Royal Music Association (RMA) and the British Forum for Ethnomusicology (BFE) declined to follow in the footsteps of their US counterparts; the RMA noted that it would take a public role if and when political actions would impact its members or music research. ${ }^{8}$

The pioneering work of Suzanne Cusick on music torture in the so-called War on Terror was crucial for the above-mentioned institutional opening. Published at the very moment when debates on torture had re-emerged in civil society, Cusick's articles gave important and much needed theoretical and musicological insights into the use and institutionalization of music in technologies of terror. ${ }^{9} \mathrm{~A}$ leading and respected musicologist in the USA and internationally, her work also legitimized musicological research on this topic. The issue of legitimation is not one to be taken lightly. Up until recently, research on music, torture and violence was met by musicologists with scepticism, if not hostility, at least in Europe. In the past I personally encountered more than once the comment "this is great research but not musicology" at the end of conference presentations of my research on music torture by the military dictatorship in Greece (1967-1974), the first documented example of a European country to sample 
coercive interrogation techniques later used by South American dictatorships ${ }^{10}$ and more recently in the detention centres of the "War on Terror". Yet even in the USA, Cusick's research was not embraced by all. It was occasionally met with awkwardness expressed in a favouring of her work on musical culture in early modern Italy. That she was elected president of the AMS (2018-2020) is telling of the changes taking place in musicology in the USA in the last decades.

Music's integral role in torture, thus, emerges as a kind of personal and collective trauma that needed to be supressed. ${ }^{11}$ The complicity of music, jewel of enlightened civilization, in the breaking of bodies, spirits and subjects turned, for some, into an open wound, a rupture in the "harmonious universe" upon which we, musicologists and ethnomusicologists, had structured our lives and subjectivities. Just like Amfortas's wound in Wagner's Parsifal, this open wound that will not heal has been inflicted by a newly acquired knowledge: music's institutionalization in technologies of terror. For some, this knowledge became a point of no return. Cusick explains how her research on music torture initiated a wound concerning her relationship with music; cultivated all her life, this relationship had been central to her subjectivity..$^{12}$ The realization that music has always been the medium of violence does not only affect us personally, she notes, but it is also "disciplinarily devastating". It falls to us, musicologists and ethnomusicologists involved in the study, performance, and reception of music, to document, fully grasp and theorize this phenomenon and its genealogy. Such research and historical recovery are not only of essence in terms of the discipline, but also a matter of urgency given political and legal issues related to current practices of terror.

6 Nowadays scepticism for these topics mostly belongs to the past, reflecting the broadening of the fields of musicology and ethnomusicology, as well as the important contribution of sound studies ${ }^{13}$ in music research. Notable is a comparison between two international conferences I co-organized in 2013 (Germany) and 2019 (Greece), for which there was an international call for papers. ${ }^{14}$ The first, Music in Detention, took place in 2013 at the University of Goettingen. It attracted 40 submissions, one third of which dealt with Nazi concentration and extermination camps during WWII. Titled Soundscapes of Trauma: Music, Violence, Therapy, the second conference took place in 2019 in Athens. There were 80 submissions, double the number, and a notable wide range of new topics; only three papers dealt with Nazi WWII camps. Fourteen years since Cusick's first article on music torture, we are no longer faced with comments questioning the place of these topics in musicology. There is a move away from the notion of music as a singularly benign artform, which had previously shaped the trajectory of music research, towards a flourishing new emerging field. Its theoretical and thematic branching out, sophistication and critical approaches are reflected in the contributions within this volume.

\section{Music Torture and the Politics of Opacity}

7 The late(nt) engagement of music research with the intersections of music and violence, and its perpetuation of biases about music's ennobling character make it politically complicit in supporting a critical blindness about music's instrumentalization as an ideal weapon of terror. Music's elusive nature has also been reinforced by the fact that it leaves no visible marks on the body. Its opacity makes it hard to prosecute in courts of law, but also to be fully grasped by the general public or 
even human rights lawyers, a point I will return to in the next section. Consequently, these practices have mostly remained undocumented and under-researched, as has music's long-standing association with power, punishment and violence. Grounded epistemologically on ancient Greek philosophy and the Enlightenment, and music's alignment with the transcendental, these perceptions conditioned public understanding about its inherently benign nature. ${ }^{15}$ They are strongly evident in the difficulty of registering music as torture in the public sphere as well as popular culture. Comments to the online article The Torture Playlist by the website Mother Jones about music torture in the "War on Terror" are indicative. ${ }^{16}$ What is striking to notice is the humorous tone of the unfolding discussion below the article. The discussion makes clear the sheer difficulty in grasping the transformation of music per se into a weapon of torture. Music's torturous quality is attributed to the genre, singer or composer rather than the practice itself, implicitly suggesting that listening to good music would create an altogether different experience.

Such positions are not limited to the uninformed online reader but are often encountered in popular culture. Woody Allen's Bananas (1971) is only one example in a string of many, humorously approaching music torture through this angle. The film's interrogation scene shows a guerrilla caught by the dictatorial regime of San Marcos. Chained on a chair, his torture solely consists of being forced to listen to the operetta Naughty Marietta. An ironic comment on opera lovers' aversion to operetta, the scene brings laughter even to the most informed audience. A similar scene in Billy Wilder's comedy One, Two, Three (1961) set in West Berlin before the building of the Berlin wall, features the song Itsy, bitsy, teeny, weeny, yellow polka dot bikini as the sole form of torture, ultimately driving the victim to a false confession. Both works humorously portray the use of music in coercive interrogation techniques. This kind of representations would be rare-if at all possible-in cinematic portrayals of physical torture like foot whipping, denailing, electroshocks or hair-pulling. What is also interesting to observe is that both comedies were released in the early 1960s and '70s, at precisely the time when these practices were emerging, indicating that these methods were not as oblique as one would expect.

Biases about music's inherently benign nature have made it difficult not only for the general public but also for survivors and perpetrators to recognize music's complicity in torture. This is notable in testimonies I collected from political prisoners of the military dictatorship in Greece (1967-1974), who were tortured with music. Even though they testified to its terrorizing effect, they initially did not view music as an integral part to the torture ritual; ${ }^{17}$ the latter consisted of a combination of interrogation techniques such as isolation, continuous standing, stress positions, sleep, food and drink deprivation and exposure to continuous music. Instead, the first assumption was that music was played from the radio in order to drown out the cries of torture. However, the Special Interrogation Unit of Greek Military Police (EAT/ESA), where they were held, did not have any civilian buildings directly adjacent to it, but was surrounded by a park, military offices and naval and military hospitals. Additionally, the cries of torture were purposefully used as a means of torture for other detainees, a method also acknowledged by Amnesty International at the time. ${ }^{18}$ Gradually over the course of the interview process, they came to realize that the same songs were played in a loop. This realization was prompted by my questions about radio programming, sequence of songs, news programmes and radio broadcasters. On 
the one hand, their difficulty speaks volumes about the elusive nature of music's role in torture. On the other, it also testifies to the fact that they did not want to "cede" music to their torturers, music being central to their discourse of resistance. Nor did they wish to credit them with the most cutting-edge torture practices of the period; there is a post-dictatorship tendency to look down on the dictators as ridiculous and kitschy individuals, a portrayal that overshadows the absolute terror in which they ruled.

The difficulty in acknowledging music's weaponization in torture is also underlined in the testimony of former Guantanamo guard Chris Arendt for the documentary Songs of War: Music as Torture..$^{19}$ As Arendt explains, he initially understood torture as inflicting acute physical pain-for instance, pulling out nails and administering electroshocks. He only later began to recognize as torture the use of blasting music in combination with stress positions, isolation, and changes between hot and cold, darkness and light. Similar cultural perceptions of what constitutes torture were echoed by a soldier of the Greek Military Police, who acted as a guard at the Special Interrogation Unit (EAT/ESA; 1972-73). He characteristically told me that they did not use scientific torture and electric wires there, but mainly their fists and legs, isolation, and forced standing, among others. ${ }^{20}$ Contrary to Arendt, he continues to remain oblivious to the fact that these were the most cutting-edge torture methods circulating internationally at the time.

\section{Coercive Interrogation and Definitions of Torture}

11 The qualitative transformation of music into a sonic weapon of torture and interrogation must be understood in the context of the human rights treaties responding to the unprecedented atrocities of World War II, the rise of international human rights law, as well as the intensification of psychological warfare during the unfolding Cold War. The preoccupation with "Soviet brainwashing" in the West, reinforced by debriefings of US soldiers returning from the Korean War, prompted the CIA's infamous mind control programme (MK Ultra) in the 1950s which included psychological research in universities in Canada, USA and the UK. ${ }^{21}$ This research constituted the basis of new interrogation techniques, aiming to effectively manipulate and collapse subjectivities of opponents in ways that could not be traced or prosecuted. The elusiveness of these techniques, and of music in particular, is therefore intentional and deeply rooted in their design and conception. Heavily relying on culturally shaped perceptions of what constitutes severe pain and suffering, and therefore torture, these methods are essentially based on manipulating captive environments. Important to note here is that they work in an accumulative manner and in combination rather than each one individually.

12 A close look at the CIA Kubark Counter Intelligence Interrogation Manual, the first manual to build on this research, shows how this new approach essentially relies on exposure to isolation, silence, continuous sound, stress positions, disorientation through sound, time deprivation and humiliations, causing a state of anxiety, fear, vulnerability and panic. ${ }^{22}$ As Kubark makes clear, continuous exposure to them can be more effective than the actual sensation of pain: "Control of an interogatee can rarely be established without control of his environment. [...] The threat to inflict pain triggers fears more damaging than the immediate sensation of pain". ${ }^{23}$ Kubark's claims have since been corroborated by research on post-traumatic stress disorder (PTSD), a mental health 
condition related to the experience or witnessing of acute trauma that can leave longlasting side-effects. Highlighting how the continued experience of fear and loss of control create a sense of "learned helplessness", it has showed that such conditions can be more detrimental than the experience of physical pain. ${ }^{24}$ These techniques aim at creating a cloud, an enclosed space that separates the detainee from his/her surroundings both physically and mentally. The only person left to relate to or depend on for support is the interrogator. Music and sound, in this context, constitute a holistic attack on the bodies and minds of detainees. Creating a sonic enclosure and obliterating any sense of external or inner space, they totalize the sense of isolation and disconnection. Detainees are unable to think, meditate or pray, but experience acute vulnerability and utter loss of control. In his testimony, Ruhal Ahmed, a former Guantanamo detainee, notes that the introduction of music to the torture ritual made the situation even worse, ${ }^{25}$ raising the stakes much higher. Music threatened his sanity, a position echoed by several others. ${ }^{26}$

13 Even though coercive interrogation techniques are usually legally deemed as cruel, inhuman and degrading (CID) treatment, they have more long-term effects than socalled physical torture with regard to PTSD. ${ }^{27}$ In this sense, it is not only the public, survivors and perpetrators who find it hard to fully grasp the impact of this kind of torture, but human rights lawyers as well. And it is precisely at this legal juncture that one has to understand the qualitative change in technologies of terror, including the transformation of music into a sonic weapon of torture. Their success in evading international law is evident in the emphasis placed on severity of pain in legal judgements concerning such interrogation techniques, debates that have recently reemerged in the context of the Guantanamo tribunal for Khalid Shaikh Mohammed, accused of planning the 9/11 attacks. According to news reports, James Mitchell, one of the psychologists to devise so-called enhanced interrogation techniques used on Mohammed, acknowledged that such methods induced "learned helplessness", arguing however that this later goes away. ${ }^{28}$ In a book detailing these techniques, he and his colleague Bill Harlow argue that even though these methods (including waterboarding) cause fear and panic, they do not constitute torture because they do not inflict severe pain. ${ }^{29}$

PTSD research contests such arguments, underlining how these techniques are linked to survivors' long-term psychological and physical conditions. Also important in proving long-term and irreparable damage caused by exposure to loud noise is the 2018 case of the viola player Christopher Goldscheider against the Royal Opera House in the UK High Court; the trial examined the ways in which exposure to acute noise during rehearsals of Wagner's Der Ring des Nibelungen caused irreparable damage to his hearing. This was the first time acoustic shock (with symptoms including tinnitus, hyperacusis and dizziness) was legally recognized as a condition which would require compensation. ${ }^{30}$ That Goldscheider has been unable to be around noise since then, experiencing pain, nausea and dizziness, underlines the long-term side effects of acoustic shock. It provides an important precedent that can be used in cases of music torture. It is precisely in these legal debates that (ethno)musicologists and sound experts can contribute through scientific studies that make this complex phenomenon and its damaging potential better understood. Collecting and analysing oral histories can address the dynamic of these methods, as well as short- and long-term effects for survivors. Additionally, theoretical insights into the use and impact of music and sound in such contexts can make clear the damaging potential they harbour. That human 
rights lawyers defending detainees have turned to musicologists' testimony in substantiating allegations of music torture underlines the need for and importance of research on this topic, both legally and politically.

The official argument defending the use of coercive interrogation techniques (misleadingly called "enhanced interrogation" techniques) in the "War on Terror" was based on the 1978 judgement of the European Court of Human Rights for the case of Ireland versus the UK. ${ }^{31}$ The trial examined charges including teaching the Royal Ulster Constabulary and authorizing five interrogation techniques against 14 IRA prisoners: hooding, wall standing, exposure to noise, reduced diet and sleep deprivation. Contrary to the report of the now defunct European Commission of Human Rights, which unanimously deemed these techniques to be torture, the court adopted a restricted meaning. It ruled that these methods amounted "only" to inhuman and degrading treatment. The judgement was not a unanimous one. Judge Dimitrios Evrigenis criticized a definition of torture based on grading the suffering inflicted, stressing the need to account for new forms of technologically sophisticated torture like this one. His remarks sadly continue to have a strong resonance today:

Torture can be practised-and indeed is practised-by using subtle techniques developed in multidisciplinary laboratories, which claim to be scientific. By means of new forms of suffering that have little in common with the physical pain caused by conventional torture it aims to bring about, even if only temporarily, the disintegration of an individual's personality, the shattering of his mental and psychological equilibrium and the crushing of his will. I should very much regret it if the definition of torture which emerges from the judgment could not cover these various forms of technologically sophisticated torture. Such an interpretation would overlook the current situation and the historical prospects in which the European Convention on Human Rights should be implemented. ${ }^{32}$

Since 1978, this grading of pain and suffering has prevailed even though both torture and CID treatment are equally banned by article 3 of the European Charter of Human Rights. Such differentiation has since been starkly challenged by research on coercive interrogation techniques and PTSD. And yet the European Court of Human Rights recently missed a historic opportunity to revise the 1978 judgment by rejecting a request submitted by Ireland in 2014. This was based on a folder of declassified files withheld by the UK government during the trial. The files included medical reports, outlining that detainees suffered from a number of psychiatric and psychosomatic symptoms related to the five-point technique; these ranged from severe to medium and mild depending on the age, medical predisposition and experience, among others. They also highlighted that the five-point interrogation techniques were used under ministerial order. What transpires from these files is that the UK had prior knowledge of the severe and long-term effects of these methods, portrayed in court at the time as minor and short-term. ${ }^{33}$ The Court's rejection mostly on technical grounds was a missed opportunity to set straight the legal shortfalls concerning a scientific method that by design aimed to cause maximum harm while evading international law. It also failed to recognize its responsibility in providing a judgement that in later years legitimated the extensive use of these methods in the "War on Terror". As Judge Siofra O'Leary noted in her dissenting opinion in 2018, an intra-state application "is not an exercise of a right of action to enforce the applicant state's rights, but an action against an alleged violation of the public order of Europe", calling for issues of public interest also to be taken into account along with legal certainty. ${ }^{34}$ 


\section{Mechanism of Music Terror} damaging potential is due to the genre or quality of performance mentioned above, or to the materiality of sound. On the one hand, there are those who suggest that a good performance of a favourite piece would not have the same effect as a genre despised by the listener or poorly performed. On the other, there are those who support that the incessant repetition of music turns it, at some point, into sound, which is true. However, music's dynamic also resides in the cultural meanings it carries with regard to class, nationality, ethnicity, religion and gender, among others. These layers of meaning also contribute to the humiliation, stress, fear and sense of vulnerability of the one forced to listen. Cusick has critically discussed the link between music torture, gender coercion and futility in the "War on Terror" ${ }^{35}$ Former detainees but also CIA operatives have spoken about the effect that certain songs-lyrics, genre, gender of singer-had on detainees, particularly those who were not raised or had not lived in Western countries. ${ }^{36}$ Furthermore, Katia Chornik has shown that in Pinochet's detention centres in Chile officers played classical music, contrary to guards and agents of the National Intelligence Directorate (DINA) who opted for popular music. ${ }^{37}$ This choice, which denotes class, was immortalized in Ariel Dorfmann's book Death and the Maiden (1990) and its cinematic rendition by Roman Polanski (1994). In my work, torture survivors of the military dictatorship in Greece repeatedly spoke about the deeply ironic and offensive nature of the songs played to them. They did not consider their choice accidental. All of them would avoid listening to these songs fifty years later. One said that he would turn off the radio, noting however that such songs are not played any more. Another survivor explained that listening to them now would make him melancholic; he was quick to add that he is generally melancholic.

Can listening to a favourite song in the context of detention, interrogation and torture lead to a different experience than sheer terror, fear and helplessness? My interviewee Maria, a former political prisoner of the military dictatorship in Greece, was clear in refuting this. Arrested in 1967, she was held for one year at the prison camps at the barren island of Giaros. There, she was not tortured but lived in inhuman conditions and was forced to listen to nationalist speeches and music, mostly folk songs and marches; this was the last remnant of the "re-education" or "rehabilitation" practices for communists and leftists practiced during the civil-war period in Greece (1946-49). ${ }^{38}$ In essence, they aimed to create a sonic enclosure that complemented their imprisonment on a barren, uninhabitable island in the midst of the Aegean Sea. Reinforced by the sound of incessant winds, this sonic enclosure was inescapable. A regular song played to them was Famous Macedonia Country of Alexander, a folk song she loved. Coming from the geographical region of Macedonia in Northern Greece, she considered it her own and used to dance it. But when this song was identified with the dictators and her oppressors, she could no longer stand listening to it. Each time it was played, she would place her fingers in her ears in an attempt to block the sound, and would feel physically sick.

Maria's nausea brings to mind Stanley Kubrick's Clockwork Orange based on the book by Anthony Burgess. Just like Maria, the main character Alex wants to vomit each time he listens to music by his favourite composer Ludwig van Beethoven-the result of an experimental "rehabilitation" programme aiming to pacify his violent nature. Chained

Transposition, Hors-série 2 | 2020 
on a chair with his eyes pinned-open by government scientists, in a scene that brings to mind images of torture, Alex is forced to watch scenes of sex and violence to the accompaniment of Beethoven's music. It is worth noting here that Burgess's book was published in 1962, a year before the Kubark manual, with which it bears similarities at parts. Indeed, the book portrays the dystopian quality of psychological experiments of the mind-control programme, showing how the ideas behind and the mechanisms of so-called brainwashing were circulating in popular culture and in the public sphere at the time. ${ }^{39}$

\section{Witnessing Music in Detention: Future Research Perspectives}

The long-term disciplinary overshadowing of music's dark side also shaped the emerging fields that took it on board. In doing so, the latter overcompensated to some extent by focusing on the negative role of music/sound in order to thoroughly document it and make a strong case, given the initial scepticism as well as the difficulty in acknowledging music's integral role in torture. This focus is also due to the long process of systematic and persistent "digging" in terms of archival and qualitative research, brushing against the grain, in order to uncover such uses, particularly for historical cases. This was, at least, my experience in investigating the previously unknown use of music in coercive interrogation techniques by the military dictatorship in Greece. Starting off this research with one survivor testimony from the proceedings of the first Torturers' Trial (1975) and a few fragments from others, I conducted archival research and numerous interviews with former political prisoners. Many of the stories I am currently working on, I owe to my interviewees and not to my own questions which mostly focused on music and sound imposed from above. Given the above-mentioned biases about music's ennobling character but also the central role it held in the discourse of resistance in Greece, testimonies kept returning to these stories; several of my interviewees talked extensively about how they used music to counter the sense of fear and terror in the very setting in which music was weaponized.

Returning to these interviews in recent years, I was able to fully appreciate the important message of entanglement they carried, calling for more nuanced listening and understanding of the ways in which music can be reclaimed or be given different meanings in the midst of abuse and unfreedom. The following examples clarify the point I wish to make. Maria, whose exposure to music from loudspeakers at Giaros prison camp was previously mentioned, was eventually able to shift the meaning of music imposed from above. By associating some of the songs with the man she was in love with at the time, she managed to withstand this inescapable listening. Or, as I have shown elsewhere, during the same period, detainees in solitary confinement faced with imposed silence reclaimed agency through humming, whistling or even coded knocking on the wall. Turning their fellow detainees into a kind of audience, into witnesses of their clandestine experience, they challenged the objectification of brutal torture to which they were exposed and which also included sound..$^{40}$ Through the faint sounds of singing and knocks on the wall, they were able to transgress imposed silence and terror. Music and sound in these settings set into motion a constitutive component of the structure of subjectivity: the ability to address an other (address-ability) and the potential of a response (response-ability). As Lacanian philosopher Mladen Dolar 
writes, we are social beings with and through the voice: voice is at the core of our social bonds and subjectivity itself, as it structurally presupposes an Other..$^{41}$ Even the pure cry (cri pur) is for psychoanalyst Jacques Lacan a cry for someone (cri pour), writes Dolar; listening to it presupposes the call and the interpolation of an other, calling for a response. ${ }^{42}$ Acousmatic sound too, such as faint knocks on the wall, can be turned into voice, attaining meaning.

This kind of witnessing, a subject that has not been given its due attention, has been beautifully portrayed in the film A Twelve Year Night (La noche de 12 años, 2018) by Álvaro Brechner. The film tells the story of three imprisoned members of the Tupamaros movement in Uruguay, Mauricio Rosencof, Eleuterio Fernándex Huidobro and José Murica (who later became president of Uruguay). Detained in solitary confinement for twelve years, they were essentially treated as hostages. The story unfolds through the ears and eyes of the detainees. Silence pervades. Throughout the film Rosencof and Huidobro devise a language through knocks on the wall in order to communicate, translated to us in the subtitles. Shared by so many political prisoners across the world around that period, this practice reminds us how strategies of survival are also international, just as the methods of torture used to break them. On their 2391st day of detention, the prisoners are transported, hooded and handcuffed, to another secret location. Once they enter their cells Rosencof, who is a poet, starts knocking to see if Huidobro is in the next cell. Relieved and emotional, he "recites" to him a poem through knocks on the wall:

\begin{tabular}{|l|l|}
\hline Y si este fuera mi último poema & And if this were my last poem \\
insumiso y triste & rebellious and sad \\
raído pero entero & worn out but whole \\
tan solo una palabra escribiría: & I would only write one word: \\
compañero & compañero \\
\hline
\end{tabular}

23 A touching moment, it speaks volumes in its elliptic language and its sounds of silence about comradery, community building, solidarity and communication in the midst of isolation, terror and abuse. Stories like these abound. Music usually features as their driving force. The prison camps on the barren island of Makronissos in Greece during the civil war, infamous for its brutal torture and indoctrination, provide my last and equally striking example. Relentlessly exposed to music and speeches from loudspeakers that made them dizzy, women political prisoners used their song to block the sound imposed from above. ${ }^{43}$ Joining their voices together, their song became an acoustic shield, countering the damaging effect of the loudspeaker, which had been turned into a sonic panopticon of power. Their song was also intended for the so-called hard-core detainees deemed impossible to "rehabilitate". Forced to stay out in the open, in natural trenches instead of tents, they were exposed to incessant winds, bitter cold or scorching sun. Recognizing and responding to their ordeal, the women's song also became a powerful tool for expressing solidarity and resistance, reinforcing community in the midst of terror.

Stories like these are not always possible. The blasting of music in the detention centres of the "War on Terror", often through earphones, obliterated the space for such attempts. However, what I have tried to underline through this brief discussion on witnessing trauma testimony is the need to ask questions that allow for other kinds of 
stories or even failed attempts to surface. Researchers need to account, wherever possible, for the sounds and music of resistance as well as of terror, otherwise we run the risk of reproducing the soundscapes of power and oppression, missing out the dynamic of music and sound in these contexts. The process of witnessing thus emerges as an ethical moment that calls us to make sense and respond to these stories, their multiple versions and voices, in ways that open up the debate about the violence and abuse of the past and the present. It allows for a kind of history-telling that emerges from below, registering all these voices and noises in the historical account, opening up unanticipated paths for our understanding of the role and impact of music in detention.

\section{BIBLIOGRAPHY}

AMERICAN MUSICOLOGICAL SOCIETY, "AMS Board Condemns the Use of Music in Physical or Psychological Torture”, AMS Newsletter, vol. 37, no. 2, August 2008, p. 5.

ANONYMous, "Royal Opera House Loses Appeal Over Viola Player's Hearing", BBC News, 17 April 2019, https://www.bbc.com/news/entertainment-arts-47965734, accessed on 25 February 2020. ANonymous, "Prisoner Abuse: Patterns from the Past", National Security Archive Electronic Briefing Book no. 122 (The National Security Archive), https://nsarchive2.gwu.edu/NSAEBB/NSAEBB122/, accessed on 23 February 2020.

AMNESTY INTERNATIONAL, “Situation in Greece”, London, 27 January 1968.

BAșoĞLU Metin, “A Multivariate Contextual Analysis of Torture and Cruel, Inhuman and Degrading Treatment: Is the Distinction Real or Apparent?", Archives of General Psychiatry, vol. 64, 2010, pp. 277-284.

BAşOĞLU Metin, "Definition of Torture in US Law. Does It Provide Legal Cover for Enhanced Interrogation Techniques?”, BAşoĞLU Metin (ed.), Torture and Its Definition in International Law. An Interdisciplinary Approach, Oxford and New York, Oxford University Press, 2017, pp. 409-432.

BAșOĞLU Metin and REYES Harnán, “Control as a Defining Characteristic of Torture. A Learning Theory Analysis of the Kubark Interrogation Manual", BAşoĞLu Metin (ed.), Torture and Its Definition in International Law. An Interdisciplinary Approach, Oxford and New York, Oxford University Press, 2017, pp. 49-59.

BRAUER Juliane, Musik im Konzentrationslager Sachsenhausen, Berlin, Metropol, 2009.

BRAUER Juliane, “How Can Music Be Torturous”, Music and Politics, vol. X no. 1, 2016, https:// dx.doi.org/10.3998/mp.9460447.0010.103.

CIA, Kubark Counter Intelligence Interrogation Manual, 1963.

CHORNIK Katia, "Music and Torture in Chilean Detention Centres: Conversations with an Ex-Agent of Pinochet's Secret Police", GRANT M. J. and PAPAETI Anna (guest eds.), the world of music (new series), Music and Torture / Music and Punishment, vol. 2, no. 1, 2013, pp. 51-65. 
CHORNIK Katia, "Should Academic Societies Make Public Statements about Political Incidents", RMA Newsletter, vol. 21, no. 2, November 2017, pp. 3-5.

CHRYTROSCHEK Tristan, Songs of War: Music as Weapon, A\&O Buro, 2010 (documentary).

CUSICK Suzanne, "Music as Torture / Music as Weapon”, Revista Transcultural de Música, Transcultural Music Review, vol. 10, 2006, https://www.sibetrans.com/trans/articulo/152/musicas-torture-music-as-weapon, accessed on 3 March 2020.

CUSICK Suzanne, “You are in a Place out of the World': Music in the Detention Camps of the Global 'War on Terror”', Journal of the Society for American Music, vol. 2, 2008, pp. 1-27.

CUSICK Suzanne, "Musicology, Torture, Repair”, Radical Musicology, vol. 3, 2008, http:// www.radical-musicology.org.uk/2008/Cusick.htm, accessed on 3 March 2020.

CUSICK Suzanne, "Toward an Acoustemology of Detention in the Global 'War on Terror"', BORN Georgina (ed.), Music, Sound and Space: Transformation of Public and Private Experience, Cambridge, Cambridge University Press, 2013, pp. 275-291.

CUSICK Suzanne, "Acoustical Violence and the End of 'Music"'. Keynote lecture at the International Conference Soundscapes of Trauma: Music, Violence, Therapy, Athens, 2019, https:// vimeo.com/394653702, accessed on 1 March 2020.

DAUGHTRY Martin, Listening to War: Sound, Music, Trauma and Survival in Wartime Iraq, Oxford and New York, Oxford University Press, 2015.

DOLAR Mladen, A Voice and Nothing More, Cambridge MA, MIT Press, 2006.

EUROPEAN COURT OF HUMAN RIGHTS, Case of Ireland versus the United Kingdom, Strasbourg, 1978, http:// cmiskp.echr.coe.int/tkp197/view.asp? action=html\&documentId=695383\&portal=hbkm\&source=externalbydocnumber\&table=F69A27FD8FB86142BF01C1166DEA398649, accessed 20 February 2020

DUFFY Aoife, "The European Court of Human Rights Exercises due Deference to Great Britain: Ireland v United Kingdom Redux", Human Rights Centre Blog, University of Essex, 17 May 2018, https://hrcessex.wordpress.com/2018/05/17/the-european-court-of-human-rights-exercisesdue-deference-to-great-britain-ireland-v-united-kingdom-redux-2018/; accessed on 20 February 2020 .

FACKLER Guido, “Music in Concentration Camps 1933-1945”, trans. Peter Logan, Music and Politics, vol. 1, no.1, 2007, https://dx.doi.org/10.3998/mp.9460447.0001.102.

GILBERT Shirli, Music in the Holocaust: Confronting Life in the Nazi Ghettos and Camps, Oxford, Clarendon Press, 2005.

Goodman Steve, Sonic Warfare: Sound, Affect and the Technology of Fear, Cambridge (MA), MIT, 2009.

GREENE Alan, "Ireland v the UK and the Hooded Men: A Missed Opportunity?", The Strasbourg Observers, 25 April 2018, https://strasbourgobservers.com/2018/04/25/ireland-v-the-uk-and-thehooded-men-a-missed-opportunity/, accessed 20 February 2020.

HERZFELD-SCHILD Marie Louise, “'He Plays on the Pillory': The Use of Musical Instruments for Punishment in Middle Ages and the Early Modern Era", PAPAETI Anna and GRANT M. J. (guest eds.), Music in Detention (thematic volume) Torture: Journal on Rehabilitation of Torture Victims and Prevention of Torture, vol. 23, no. 2, 2013, pp. 14-23. 
INGRAM Martin, "Juridical Folklore in England Associated with Rough Music", BROoKs Christopher and LOBBAN Michael (eds.), Communities and Courts in Britain (1150-1900), London, Hambledon Press, 1997, pp. 61-82.

LABELLE Brandon, Acoustic Territories: Sound Culture and Everyday Life, New York and London, Continuum, 2010.

MccoY Alfred W, A Question of Torture. CIA Interrogation. From the Cold War to the War on Terror, New York, Henry Holt and Co., 2006.

MCDERMOTT Terry, "In 9/11 Proceedings, Once-Forbidden Topic Is Front and Center: Torture”, LA Times, 20 January 2020, https://www.latimes.com/world-nation/story/2020-01-20/ksmguantanamo-trial-torture, accessed on 25 February 2020.

MITCHELL James with HARLOW Bill, Enhanced Interrogation. Inside the Minds and Motives of the Islamic Terrorists Trying to Destroy America, New York, Crown Forum, 2016.

GRANT M. J., “'Human Rights Have Made a Difference': An Interview with Manfred Nowak”, GRANT M. J. and PAPAETI Anna (guest eds.), the world of music (new series): Music and Torture / Music and Punishment, vol. 1, no. 2, (2013), pp. 97-98.

NALBADIDACIS Janis, In the Dungeons of the Dictatorship: A Comparative Study of Centres of Torture in Argentina and Greece during the last Military Dictatorships, $\mathrm{PhD}$ thesis, Humboldt University, Berlin, 2019).

MORRISON James, "CIA Mind-Control Trials Revealed as Secret Inspiration Behind 'A Clockwork Orange”", The Independent, 13 October 2002. https://www.independent.co.uk/arts-entertainment/ films/news/cia-mind-control-trials-revealed-as-secret-inspiration-behind-a-clockworkorange-139895.html, accessed 27 February 2020.

NALIWAJEK-MAZUREK Katarzyna, "Music and Torture in Nazi Sites of Persecution and Genocide in Occupied Poland 1939-1945”, GRANT M. J. and PAPAETI Anna (guest eds.), the world of music (new series): Music and Torture / Music and Punishment, vol. 2, no.1, 2013, pp. 31-50.

PAPAETI Anna, "Music, Torture, Testimony: Re-Opening the Case of the Greek Junta (1967-1974)," GRANT M. J. and PAPAETI Anna (guest eds.), Music and Punishment / Music and Torture (special volume) the world of music (new series), vol. 1, no. 2, 2013, pp. 67-89.

PAPAETI Anna, "Music and Re-Education in Greek Prison Camps: From Makronisos (1947-53) to Giaros (1967-68)", PAPAETI Anna and GRANT M. J. (guest eds.), Torture: Journal on Rehabilitation of Torture Victims and Prevention of Torture: 'Music in Detention', vol. 23, n. 2, 2013, pp. 34-43.

PAPAETI Anna, "Singing out Terror: Music Communities in the Detention Centres of the Military Dictatorship in Greece (1967-1974)”, THEODOSIOU Aspasia and KALLIMOPOULOU Eleni (eds.), Music Communities in Greece of the 21st Century: Ethnographic Listening and Perspectives (forthcoming, in Greek).

PLATO, Republic, ed. FERRARI G.R.F., trans. T. Griffith, Cambridge, Cambridge University Press, 2000. PROVENZA Antonietta, “Aristoxenus and Music Therapy”, HUFFMANN C.A. (ed.), Aristoxenus of Tarentum. Discussion, New Brunswick and London, Transaction, 2011, pp. 91-128.

Ross Alex, “When Music Is Violence”, The New Yorker, 27 January 2016, https:// www.newyorker.com/magazine/2016/07/04/when-music-is-violence, accessed on 2 March 2020. RICE Timothy. "Ethnomusicology in Times of Trouble," Yearbook for Traditional Music, vol. 46, 2014, pp. 191-209. 
SHARROCK Justine, “The Torture Playlist”, Mother Jones, 22 February 2008, https://

www.motherjones.com/politics/2008/02/torture-playlist/, accessed on 20 February 2020.

SOCIETY FOR AMERICAN MUSIC, "Resolutions Introduced at the SAM Business Meeting, 3 March 2007, https://www.american-music.org/page/Resolutions, accessed on 23 February 2020.

SOCIETY FOR ETHNOMUSICOLOGY, "Position Statement on Torture", 2 February 2007, https://

www.ethnomusicology.org/page/PS_Torture, accessed on 23 February 2020.

THEOPHRASTUS, Theophrastus of Eresus. Commentary, vol. 6.1. Sources of Ethics, ed. FORTENBAUCH W.W., Leiden and Boston, Brill, 2011.

THOMPSON E.P., “Rough Music Reconsidered”, Folklore, vol. 3, no. 1, 1992, pp. 3-26.

TSETSOs Markos, Music in Modern Philosophy. From Kant to Adorno, Athens, Alexandria, 2012 (in Greek).

VERVENIOTI Tasoula, "Maronisi: Testimonies of Women", BOURNAZOS Stratis and SAKELLAROPOULOS Tassos (eds.), Historical Place and Historical Memory: The Paradigm of Makronissos, Athens, Philistor, 2000, pp. 103-114.

WORTHINGTON Andy, "Hit me Baby One More Time”, Counterpunch, 15 October 2008, https:// www.counterpunch.org/2008/12/15/hit-me-baby-one-more-time/, accessed on 2 March 2020.

\section{NOTES}

1. See, for instance, HERZFELD-SCHILD Marie Louise, “'He Plays on the Pillory': The Use of Musical Instruments for Punishment in Middle Ages and the Early Modern Era", PAPAETI Anna and GRANT M. J. (guest eds.), Music in Detention (thematic volume) Torture: Journal on Rehabilitation of Torture Victims and Prevention of Torture, vol. 23, no. 2, 2013, pp. 14-23; INGRAM Martin, "Juridical Folklore in England Associated with Rough Music", вRоокs Christopher and LOBBAN Michael (eds.), Communities and Courts in Britain (1150-1900), London, Hambledon Press, 1997, pp. 61-82; тHOMPSON E.P., "Rough Music Reconsidered", Folklore, vol. 103, no. 1, 1992, pp. 3-26.

2. See, for instance, BRAUER Juliane, Musik im Konzentrationslager Sachsenhausen, Berlin, Metropol, 2009; BRAUER Juliane, "How Can Music Be Torturous," Music and Politics, vol. X, no. 1, 2016; FACKLER Guido, "Music in Concentration Camps 1933-1945", trans. Peter Logan, Music and Politics, vol. 1, no.1, 2007; GILBERT Shirli, Music in the Holocaust: Confronting Life in the Nazi Ghettos and Camps, Oxford, Clarendon Press, 2005; NALIWAJEK-MAZUREK Katarzyna, "Music and Torture in Nazi Sites of Persecution and Genocide in Occupied Poland 1939-1945", GRANT M. J. and PAPAETI Anna (guest eds.), the world of music (new series): Music and Torture / Music and Punishment, vol. 2, no.1, 2013, pp. 31-50.

3. RICE Timothy, 2014. "Ethnomusicology in Times of Trouble," Yearbook for Traditional Music, vol. 46, pp. 191-209.

4. cusick Suzanne G. "Acoustical Violence and the End of "Music". Keynote lecture at the international conference Soundscapes of Trauma: Music, Violence, Therapy, Athens 2019, https:// vimeo.com/394653702, accessed on 1 March 2020.

5. SOCIETY FOR ETHNOMUSicology, "Position Statement on Torture", 2 February 2007, https:// www.ethnomusicology.org/page/PS_Torture, accessed on 23 February 2020.

6. SOCIETY FOR AMERICAN MUSIC, "Resolutions Introduced at the SAM Business Meeting", 3 March 2007, https://www.american-music.org/page/Resolutions, accessed on 23 February 2020.

7. american musicological society, "AMS Board Condemns the Use of Music in Physical or Psychological Torture”, AMS Newsletter, vol. 37, no. 2, August 2008, p. 5. 
8. сHORNIK Katia, "Should Academic Societies Make Public Statements about Political Incidents", RMA Newsletter, vol. 21, no. 2, November 2017, pp. 3-5. In 2016 the Annual Conference of the Royal Music Association (UK) included the panel "Music, Violence, Justice". The 2017 annual conference of the British Forum of Ethnomusicology hosted the round table themed "Ethics and Aesthetics of Studying Music in Situations of Conflict and Violence"; its success led to a participatory workshop in 2018.

9. cusick Suzanne, "Music as Torture / Music as Weapon", Revista Transcultural de Música, Transcultural Music Review, vol. 10, 2006; сusick Suzanne, “You are in a Place out of the World': Music in the Detention Camps of the Global 'War on Terror"', Journal of the Society for American Music, vol. 2, 2008, pp. 1-27; cusick Suzanne, "Musicology, Torture, Repair”, Radical Musicology, vol. 3, 2008; cusick Suzanne, “Toward an Acoustemology of Detention in the Global 'War on Terror"', BORN Georgina (ed.), Music, Sound and Space: Transformation of Public and Private Experience, Cambridge, Cambridge University Press, 2013, pp. 275-291.

10. CHORNIK Katia, "Music and Torture in Chilean Detention Centres: Conversations with an ExAgent of Pinochet's Secret Police", GRANT M. J. and PAPAETI Anna (guest eds.), the world of music (new series), Music and Torture / Music and Punishment, vol. 2, no. 1, 2013, pp. 51-65; NALBADIDACIS, Janis, In the Dungeons of the Dictatorship: A Comparative Study of Centres of Torture in Argentina and Greece during the last Military Dictatorships, PhD thesis 2019, Humboldt University, Berlin, pp. 155-156.

11. Cusick has spoken about the link of music to violence as a deep-seated trauma of musicology. See, cusick, "Acoustical Violence".

12. Ibid.

13. See, for instance, DAUGHTRY Martin, Listening to War: Sound, Music, Trauma and Survival in Wartime Iraq, Oxford and New York, Oxford University Press, 2015; GoodmAN Steve, Sonic Warfare: Sound, Affect and the Technology of Fear, Cambridge (MA), MIT, 2009; LABELLE Brandon, Acoustic Territories: Sound Culture and Everyday Life, New York and London, Continuum, 2010.

14. The conferences were organized in the context of two Marie Curie Fellowships I held at the University of Goettingen (acronym MUSTERMAN; https://www.uni-goettingen.de/en/ music+in+detention\%2C+two-day+international+conference/364762.html) and Panteion University of Social and Political Sciences, Athens, respectively (acronym MUSDEWAR; https:// soundscapesofdetention.com/conference/).

15. THEOPHRASTUS, Theophrastus of Eresus. Commentary. Sources of Ethics, vol. 6, no. 1, ed. FORTENBAUCH W.W., Leiden and Boston, Brill, 2011; TSETSOs Markos, Music in Modern Philosophy. From Kant to Adorno, Athens, Alexandria, 2012 (in Greek); PLATo, Republic, ed. FERRARI G.R.F., trans. T. Griffith, Cambridge, Cambridge University Press, 2000; PRovenZA Antonietta, "Aristoxenus and Music Therapy", huffmann C.A. (ed.), Aristoxenus of Tarentum. Discussion, New Brunswick and London, Transaction, 2011, pp. 91-128.

16. SHARRock Justine, "The Torture Playlist", Mother Jones, https://www.motherjones.com/ politics/2008/02/torture-playlist/, 22 February 2008, accessed on 20 February 2020. Suzanne Cusick critically discusses in length reactions on music torture in the blogosphere, underlining the undertones of homophobia and heterosexual fantasy. cusick, "Music as Torture / Music as Weapon".

17. See, PAPAETI Anna, "Music, Torture, Testimony: Re-Opening the Case of the Greek Junta (19671974)", GRANT M. J. and PAPAETI Anna (guest eds.), Music and Punishment / Music and Torture (special volume) the world of music (new series), vol. 1, no. 2, 2013, pp. 67-89.

18. AMNESTY INTERNATIONAL, "Situation in Greece", London, 27 January 1968, p. 4.

19. CHRYTROSCHEK Tristan, Songs of War: Music as Weapon, A\&O Buro, 2010; documentary.

20. Interview with Yannis, Athens 2012. 
21. Mccoy Alfred W, A Question of Torture. CIA Interrogation. From the Cold War to the War on Terror, New York, Henry Holt and Co., 2006. See also CHRYTROsCHEK, Songs of War; cusicK, "Music as Torture / Music as Weapon".

22. CIA, Kubark Counter Intelligence Interrogation Manual, 1963. In a secret 1992 report written for the Secretary of Defence Dick Cheney, Kubark and later manuals based on these concepts were condemned as containing "offensive and objectionable material [...] concerning respect for human rights". See AnonYmous, "Prisoner Abuse: Patterns from the Past", National Security Archive Electronic Briefing Book no. 122 (The National Security Archive), https://nsarchive2.gwu.edu/ NSAEBB/NSAEBB122/, accessed on 23 February 2020.

23. CIA, pp. $4,86$.

24. On coercive interrogation techniques and "learned helplessness", see BASOĞLOU Metin (ed.), Torture and Its Definition in International Law. An Interdisciplinary Approach, Oxford and New York, Oxford University Press, 2017, pp. 49-59, 409-432.

25. Ruhal Ahmed testimony, https://www.youtube.com/watch?v=_EuIlAiFWQc, accessed on 20 February 2020.

26. Binyam Mohamed's testimony relayed by his lawyer Clive Stafford Smith in a video campaign against music torture by the non profit organization Reprieve, https://www.youtube.com/ watch?v=B5Cglt_MdF8, accessed on 20 February 2020.

27. BASOĞLOU Metin, "A Multivariate Contextual Analysis of Torture and Cruel, Inhuman and Degrading Treatment: Is the Distinction Real or Apparent?", Archives of General Psychiatry, vol. 64, 2010, pp. 277-284; BASOĞLOU Metin, "Definition of Torture in US Law. Does It Provide Legal Cover for Enhanced Interrogation Techniques?", BASoĞLou Metin (ed.), Torture and Its Definition in International Law. An Interdisciplinary Approach, Oxford and New York, Oxford University Press, 2017, pp. 409-432; BASOĞLOU Metin and REYES Harnán, "Control as a Defining Characteristic of Torture. A Learning Theory Analysis of the Kubark Interrogation Manual”, ibid, pp. 49-59.

28. MCDERMOTT Terry, "In 9/11 Proceedings, Once-Forbidden Topic Is Front and Center: Torture", LA Times, 20 January 2020, https://www.latimes.com/world-nation/story/2020-01-20/ksmguantanamo-trial-torture, accessed on 25 February 2020.

29. MITCHELL James with HARLOW Bill, Enhanced Interrogation. Inside the Minds and Motives of the Islamic Terrorists Trying to Destroy America, New York, Crown Forum, 2016.

30. ANONYMOUS, "Royal Opera House loses appeal over viola player's hearing", BBC News, https:// www.bbc.com/news/entertainment-arts-47965734, accessed on 25 February 2020.

31. eUROPEAN COURT OF HUMAN RIGHTS, "Case of Ireland versus the United Kingdom, 1978", Strasbourg, http://cmiskp.echr.coe.int/tkp197/view.asp? action=html\&documentId=695383\&portal=hbkm\&source=externalbydocnumber\&table=F69A27FD8FB86142BF01C1166DEA398649, accessed 20 February 2020.

32. Judge Dimitrios Evrigenis cited in ibid., 124.

33. See DUFFY Aoife, "The European Court of Human Rights Exercises due Deference to Great Britain: Ireland v United Kingdom Redux", Human Rights Centre Blog, University of Essex, 17 May 2018, https://hrcessex.wordpress.com/2018/05/17/the-european-court-of-human-rightsexercises-due-deference-to-great-britain-ireland-v-united-kingdom-redux-2018/, accessed 20 February 2020; GREENE Alan, "Ireland v the UK and the Hooded Men: A Missed Opportunity?", The Strasbourg Observers, 25 April 2018, https://strasbourgobservers.com/2018/04/25/ireland-v-theuk-and-the-hooded-men-a-missed-opportunity/, accessed 20 February 2020.

34. Cited in GREENE, "Ireland $\mathrm{v}$ the UK and the Hooded Men".

35. CUSICK, "You are in a Place out of the World", pp. 1-27.

36. WORTHINGTON Andy, "Hit me Baby One More Time”, Counterpunch, 15 October 2008, https:// www.counterpunch.org/2008/12/15/hit-me-baby-one-more-time/, accessed on 2 March 2020;

Transposition, Hors-série 2| 2020 
Ross, Alex, "When Music Is Violence", The New Yorker, 27 June 2016, https:// www.newyorker.com/magazine/2016/07/04/when-music-is-violence, accessed on 2 March 2020. 37. CHORNIK, "Music and Torture", pp. 57-58.

38. See PAPAETI Anna, "Music and Re-Education in Greek Prison Camps: From Makronisos (19471953) to Giaros (1967-1968)", PAPAETI Anna and GRANT M. J. (guest eds.), Torture: Journal on Rehabilitation of Torture Victims and Prevention of Torture: 'Music in Detention', vol. 23, no. 2, 2013, pp. 34-43.

39. M. J. Grant discusses these similarities in brief in “'Human Rights Have Made a Difference': An Interview with Manfred Nowak", the world of music (new series): Music and Torture / Music and Punishment, vol. 1, no. 2 (2013), pp. 97-98. Burgess' biographer Roger Lewis has speculated that the author was aware of the CIA mind control programme through his employment at the Colonial Services in Malaya, an argument that has, nevertheless, not been substantiated by evidence. MORRISON James, "CIA Mind-Control Trials Revealed as Secret Inspiration Behind 'A Clockwork Orange", The Independent, 13 October 2002,

https://www.independent.co.uk/arts-entertainment/films/news/cia-mind-control-trials-

revealed-as-secret-inspiration-behind-a-clockwork-orange-139895.html, accessed 27 February 2020.

40. PAPAETI Anna, "Singing out Terror: Music Communities in the Detention Centres of the Military Dictatorship in Greece (1967-1974)", THEODOSIOU Aspasia and KALLIMOPOULOU Eleni, Music Communities in Greece of the 21st Century: Ethnographic Listening and Perspectives (forthcoming, in Greek).

41. Dolar Mladen, A Voice and Nothing More, Cambridge MA, MIT Press, 2006, p. 14.

42. Ibid., pp. 27-28.

43. VERVENIOTI Tasoula, "Makronisi: Testimonies of Women", BOURNAZOS Stratis and SAKellaropoulos Tassos (eds.), Historical Place and Historical Memory: The Paradigm of Makronissos, Athens, Philistor, 2000, p. 109.

\section{ABSTRACTS}

This essay explores the late engagement of music research with the long-standing yet overlooked association between music, violence and terror. In mapping this new field, it seeks to understand this latency as a disciplinary trauma. It examines music's integral role in new technologies of terror emerging during the Cold War, the cultural biases that have turned it into an elusive means of torture, and the effects stemming from the overshadowing of its damaging potential. Focusing on the notion of witnessing, it highlights the need for more nuanced soundscapes of detention that explore the entanglement of negative and positive uses of music as they are imposed from above and reclaimed from below.

Cet article interroge le caractère tardif de l'intérêt de la recherche musicologique pour l'association durable et néanmoins négligée entre musique, violence et terreur. En cartographiant ce nouveau champ de recherche, il s'agit de comprendre une telle période de latence en tant que traumatisme disciplinaire. Il s'agit aussi d'examiner le rôle constitutif de la musique dans les nouvelles technologies de la terreur issues de la guerre froide, les préjugés culturels qui l'ont transformée en un moyen de torture difficile à saisir ainsi que les effets qui 
découlent de l'ignorance de son potentiel de nuisance. Mettant l'accent sur la notion de témoignage, l'article souligne la nécessité de concevoir des paysages sonores plus nuancés pour les espaces de détention, en explorant les usages négatifs et positifs de la musique tels qu'ils sont imposés d'en haut ou réappropriés d'en bas.

\section{INDEX}

Keywords: music, detention, violence, torture, inhuman and degrading treatment, subjectivity, witnessing, musicology, ethnomusicology

Mots-clés: musique, détention, violence, torture, traitements inhumains et dégradants, subjectivité, témoignage, musicologie, ethnomusicologie

\section{AUTHOR}

\section{ANNA PAPAETI}

Anna Papaeti writes about opera and musical theatre, the nexus of music, trauma, and violence, and the interlinking of ethics, politics, and aesthetics. Her post-doctoral research has been supported by Marie Skłodowska Curie Actions (FP7, Horizon 2020), Research Centre for the Humanities, Athens, Onassis Foundation, and DAAD. She has co-edited two journal volumes on music, torture, and detention, and has written widely on the topic. She has also created the (sound) installations The Dark Side of the Tune (2016) and New Parthenon (2019) with Nektarios Pappas, and the podcast The Undoing of Music (Museo Reina Sofía, Madrid, 2018). 